\title{
Blaines Beware: Trinity Lutheran and the Changing Landscape of State No-Funding Provisions
}

\author{
Matthew Sondergard*
}

\section{INTRODUCTION}

For most Americans, religion and politics are like oil and water. They do not, and should not, mix. The tension between the two topics is evident, even from a cursory view at the news. The Supreme Court's decision in Trinity Lutheran Church of Columbia, Inc. v. Comer has highlighted this conflict once again. Due to the constant public debate regarding the relationship between religion and politics, Trinity Lutheran will have a substantial impact on the religious freedom landscape for decades to come.

Locally, this decision impacts Kansas's constitution. Article 6, Section 6 of the Kansas Constitution describes how education funding will occur in Kansas. ${ }^{1}$ Recently, this topic has been a battleground between the Kansas courts and the Kansas Legislature. ${ }^{2}$ At the end of this section is clause (c). This clause is short, only containing fourteen words, yet it sets the stage for potential litigation in Kansas under the United States Supreme Court's decision in Trinity Lutheran. Due to its simplicity, clause (c) is very clear: "No religious sect or sects shall control any part of the public educational funds." ${ }^{3}$ This section is one of many sections in various state constitutions prohibiting state funding from going to

\footnotetext{
* J.D. Candidate, Dec. 2018, University of Kansas School of Law; B.S. Political Science, Kansas State University, 2015. I would like to thank Professor Stephen McAllister for his invaluable insight on this topic. I would also like to thank Mathew Petersen, Nell Neary, Nick Snow, and the rest of the Kansas Law Review staff for their diligent and helpful review of this Comment. Lastly, I would like to thank my wife Jessica for her steadfast love and support.

1. KAN. CONST. art. $6, \S 6(\mathrm{c})$. Kansas's no-funding provision has moved around Article 6. At its creation, the provision was in Article 6, Section 8 but after the 1966 amendments to Article 6 it was shuffled to its current position in $\S 6$ in order to "emplace a modern approach to public education." Francis H. Heller, The Kansas State Constitution: A ReferenCe Guide 98-103 (1992).

2. Craig Martin \& John Rury, The Kansas Education Funding Case and Constitutional Democracy, HufFPost (Jan. 16, 2009, 8:07 AM), http://www.huffingtonpost.com/craigmartin/kansas-school-funding_b_6481840.html.
}

3. KAN. CONST. art. 6, §6(c). 
religious educational institutions. ${ }^{4}$ These sections, typically called Blaine Amendments or no-funding provisions, have a very controversial past and potentially, a controversial future.

In June 2017, the United States Supreme Court found that the State of Missouri violated the Free Exercise Clause and discriminated against Trinity Lutheran Church when it prevented them from receiving funding for a public grant program. ${ }^{5}$ This decision opened the door to question the constitutionality of Blaine Amendments. The Court's rationale in Trinity Lutheran and past precedent indicate that these no-funding provisions, including Kansas's Article 6, Section 6(c), are unconstitutional under the Free Exercise Clause of the Constitution. The potential repercussions of this rationale could lead to public funding for religious schools.

This Comment addresses the statutory impact Trinity Lutheran will have on Article 6, Section 6(c) of the Kansas Constitution. Considering the Court's Trinity Lutheran holding in conjunction with prior precedents Zelman v. Selman-Harris ${ }^{6}$ and Locke v. Davey, ${ }^{7}$ Kansas's no-funding provision (and other similar state statutes) is likely unconstitutional as applied to indirect educational funding. Further, at least in some applications, Zelman and Trinity Lutheran provide a test for future religious freedom cases involving indirect governmental funding.

Part II examines the background of Blaine Amendments generally, Kansas's Blaine Amendment, and analysis of the Supreme Court's decisions in Zelman v. Selman-Harris, Locke v. Davey and Trinity Lutheran Church of Columbia, Inc. v. Comer. Part III analyzes Trinity Lutheran's impact on Kansas's state constitutional provisions that bar various types of state funding for religious institutions, its impact on the federal doctrine of separation of church and state, and policy implications for the school-choice movement.

\section{BACKGROUND}

\section{A. Blaine Amendments}

Throughout American history, Blaine Amendments occupy a

4. Mark Edward DeForrest, An Overview and Evaluation of State Blaine Amendments: Origins, Scope, and First Amendment Concerns, 26 HARV. J.L. \& PUB. POL'Y 551, 576-602 (2003).

5. Trinity Lutheran Church of Columbia, Inc. v. Comer, 137 S. Ct. 2012, 2024-25 (2017).

6. Zelman v. Simmons-Harris, 536 U.S. 639, 662-63 (2002) (holding a state sponsored school voucher program did not violate the Establishment Clause).

7. Locke v. Davey, 540 U.S. 712, 725 (2004) (holding Washington's Blaine Amendment did not unconstitutionally prevent Locke from studying theology). 
relatively unknown place. While opposition to these Amendments has existed since their inception, it is only recently that courts have started pushing back against these no-funding provisions. ${ }^{8}$ Blaine Amendments are state constitutional provisions that bar various types of state funding for religious institutions. ${ }^{9}$ They can be relatively simple, like the Kansas provision, which only bars public funding of religious schools, or they can be comprehensive and cover all manners of public funding for religious institutions. ${ }^{10}$ These provisions have been a part of the American legal landscape since the Nineteenth Century, and they owe their purpose to their namesake, James Blaine. ${ }^{11}$

\section{History of the Federal Blaine Amendment}

Religious rights are some of the most cherished rights recognized by the Bill of Rights. ${ }^{12}$ The First Amendment recognizes two religious rights, the freedom from "law respecting an establishment of religion," and freedom from laws "prohibiting the free exercise thereof."13 In simpler terms, these clauses prevent the state from establishing a state church, like the Church of England or Church of Denmark, and prevent the establishment of laws that unduly interfere with the practice of religion. ${ }^{14}$ Very few cases involving these rights went to the Supreme Court before the 1940s. ${ }^{15}$ After the 1940s, more states began incorporating these rights

8. See e.g., Trinity Lutheran, 137 S. Ct. 2012; Schwartz v. Lopez, 382 P.3d 886, 900 (Nev. 2016) (holding while a state educational savings account program violated the Nevada constitution, the program did not violate Nevada's Blaine Amendment).

9. Jill Goldenziel, Blaine's Name in Vain?: State Constitutions, School Choice, and Charitable Choice, 83 DENV. U. L. REv. 57, 58 (2005).

10. See id. at $68-95$ (comparing the various types of Blaine Amendments).

11. DeForrest, supra note 4, at 556-57.

12. John Witte, Jr., The Essential Rights and Liberties of Religion in the American Constitutional Experiment, 71 Notre DAme L. ReV. 371, 377-88 (1996) (exploring the importance of religious rights to various factions in colonial America).

13. U.S. CONST. amend. I.

14. Everson v. Bd. of Educ., 330 U.S. 1, 15-16 (1947) (“The 'establishment of religion' clause of the First Amendment means at least this: Neither a state nor the Federal Government can set up a church. Neither can pass laws which aid one religion, aid all religions, or prefer one religion over another ... No tax in any amount, large or small, can be levied to support any religious activities or institutions, whatever they may be called, or whatever form they may adopt to teach or practice religion ... In the words of Jefferson, the clause against establishment of religion by law was intended to erect 'a wall of separation between Church and State."' (quoting Reynolds v. United States, 98 U.S. 145, 164 (1878)); see also Church of Lukumi Babalu Aye, Inc. v. City of Hialeah, 508 U.S. 520, 532 (1993) (" $[\mathrm{T}]$ he protections of the Free Exercise Clause pertain if the law at issue discriminates against some or all religious beliefs or regulates or prohibits conduct because it is undertaken for religious reasons.").

15. Mark David Hall, Jeffersonian Walls and Madisonian Lines: The Supreme Court's Use of History in Religious Clauses Cases, 85 OR. L. REV. 563, 570 (2006). 
and cases involving religious rights became more common. ${ }^{16}$ This application, however, fails to recognize that issues revolving around these rights existed before their application to individual states. In particular, the Blaine Amendment and its offspring have spawned various religious rights debates and will continue to spawn these debates until the United States Supreme Court sets a clear path forward.

Blaine Amendments have long been a point of controversy in the First Amendment sphere. They have had a large influence on litigation surrounding funding of religious institutions because state courts' rely upon them to deny state funding to religious entities/purposes, even where federal precedent would allow it. ${ }^{17}$ The Blaine Amendment originated in 1875 when House Speaker James Blaine argued for an amendment to the United States Constitution which would prohibit the public funding of religious schools. ${ }^{18}$ Spurred on by a speech made by President Grant, Blaine, a representative from Maine, laid out his proposal. ${ }^{19}$ The proposal stated:

No State shall make any law respecting an establishment of religious or prohibiting the free exercise thereof; and no money raised by taxation in any State for the support of the public schools, or derived from any public fund therefore, nor any public lands devoted thereto, shall ever be under the control of any religious sect, nor shall any money so raised or lands so devoted be divided between religious sects or denominations. ${ }^{20}$

Blaine's proposal conflicted members of the Democratic Party. ${ }^{21}$ They did not want to alienate Catholics, who represented a large part of their constituency, but drawing close to Catholicism would leave them vulnerable to Republican attacks. ${ }^{22}$ To make the amendment more palatable, House Democrats inserted a limiting clause which reduced the

16. Id.; see e.g., Cantwell v. Connecticut, 310 U.S. 296, 303-04 (1940); see also Locke v. Davey, 540 U.S. 712, 718-19 (2004).

17. Mechthild Fritz, Religion in a Federal System: Diversity Versus Uniformity, 38 U. KaN. L. REV. 39, 70 (1989) ("States tend to rely upon more specific state constitutional provisions that prohibit public subsidies to religious institutions or for religious purposes, or that prohibit financial compulsion to support religion.").

18. DeForrest, supra note 4, at 556.

19. Id. at 558 .

20. H.R.J. Res. 1, 44th Cong. (1875).

21. DeForrest, supra note 4, at 566 ("As the Blaine Amendment was debated, Democratic politicians were caught between a rock and a hard place. They had no desire to alienate Catholic voters - a key voting block for the Democratic Party - but they had no desire to appear to be too closely connected with the Catholic Church either.").

22. Id. 
amendment to a "statement of principles.", proposal with fervor, and it passed 180 to $7 .^{24}$

However, the Senate gave the proposal a lukewarm greeting where it failed to gather the necessary votes. ${ }^{25}$ Senate Republicans disfavored the weakened amendment and sought to expand it. ${ }^{26}$ The final Senate vote on the amended House version was 28 in favor, 16 against and 27 absentshort of the necessary two-thirds majority required. ${ }^{27}$ The controversial nature of this debate is exemplified by the fact that newly minted Senator Blaine, the original author of the amendment, voted to abstain in the final vote. $^{28}$ Though Blaine's plan failed, his idea endured. State legislatures took up Blaine's cause as they added amendments modeled on the Federal Blaine Amendment to their state constitutions. ${ }^{29}$ Today, roughly thirty states have some type of Blaine Amendment or no-funding provision. ${ }^{30}$

\section{Motivations Behind the Blaine Amendments}

Most historians are convinced that motivation fueling the Blaine Amendments was colored by anti-Catholic views. ${ }^{31}$ Public schools were viewed as a bastion of Protestantism and served, "as a defense of democratic values, rather than the values of a particular religious tradition." 32 As a response to the Protestant nature of the public schools, Catholic schools were established. ${ }^{33}$ In Blaine's era, this connection between Protestantism and the public schools was under siege. There was a movement to remove the King James Bible from the educational system

\footnotetext{
23. Id. at $567-68$.

24. Id. at 568 .

25. Id. at 573 .

26. Id. at $568-73$.

27. Id. at 573 .

28. Id.

29. Id. at $573-75$. (2000).

30. Toby J. Heytens, Note, School Choice and State Constitutions, 86 VA. L. REV. 117, 134

31. See e.g., DeForrest, supra note 4, at 559-73; Stephen K. Green, The Blaine Amendment Reconsidered, 36 AM. J. LEGAL HIST. 38, 69 (1992) ("The Blaine Amendment was the direct result of Republican attempts to gain political mileage from a growing concern over Catholic and immigrant inroads into American culture."); but see Jill Goldenziel, supra note 9, at 62 ("Only scant historical records and incomplete constitutional convention journals document the enactment of these amendments in the states, and the few available accounts reveal little evidence of bigotry. Whatever anti-Catholic animus might have lain behind the no-funding provisions at their inception has not yet been shown to influence current state jurisprudence.").

32. DeForrest, supra note 4, at 560.

33. Id. at 571 ("Catholics were not opposed to paying taxes for schools, nor were they opposed to the principle of free education; rather, Catholics were opposed to paying taxes and sending their children to schools that would indoctrinate their children in Protestant sectarianism.").
} 
and Catholic leaders in America pushed for government funding of a separate Catholic education system. ${ }^{34}$ As Catholic immigration to America continued to grow, Catholic political power grew alongside it. ${ }^{35}$

This influx of Catholic immigrants and power spawned anti-Catholic sentiment in much of the American public. Both Republicans and Democrats dipped into the anti-Catholic fervor to gain political strength, yet the Republicans went the farthest with it. ${ }^{36}$ The anti-Catholic purpose behind the proposed federal Blaine Amendment was more apparent in the debates that occurred during this time. Senator Edmunds, a Republican Senator from Vermont, attacked the Catholic Church on the floor of the Senate, arguing that while the proposed amendment would only stop Catholicism from being supported, generic Protestantism would generally still be accepted in the public sphere. ${ }^{37}$ Although the federal Blaine Amendment ultimately failed to pass, the underlying anti-Catholic purpose of the amendment trickled into many state constitutions. ${ }^{38}$ In summation, there were two main motivations behind the Blaine Amendments. First, a fear of the growing political power of Catholics, and second, the protection of the "generic Protestant religiosity in the common schools and the public square." 39

\section{State Blaine Amendments}

State Blaine Amendments come in all shapes and sizes. While quite common-roughly thirty state constitutions contain them-their varied interpretations can make it difficult to place them in a singular box. ${ }^{40}$ The states that adopted these amendments tended to do so either willingly or

34. Id. at 560 ("This effort was, at its core, a quest for equity. Catholics were forced to pay taxes to support the Protestant common schools, and it was only fair, from the Catholic perspective, that Catholic schools also be eligible for public funding. In lieu of direct public funding for parochial schools, an appeal was made for Catholic parents to receive tax rebates equal to the amount of their tax bills that went to fund the Protestant common schools.").

35. Id. at $560-62$.

36. Id. at 564 .

37. Id. at 570-71 ("Edmunds sought to distinguish religion - the general principles of morality and faith that could be attributed to the kind of generic Protestantism that had formed the common schools from the beginning-from sectarianism, i.e., Catholicism. In short, desacralized Protestantism, would remain welcome in the common schools and other public institutions.").

38. Id. at 573 .

39. Id. at 602 .

40. Id. at 576 (surveying the various state Blaine Amendments). 
in order to gain statehood. ${ }^{41}$ When analyzing these laws, it's helpful to break them down relative to their strength. ${ }^{42}$

The weakest Blaine Amendments focus solely on education. ${ }^{43}$ This class of amendments were designed to prevent any direct public support for religious education, but have minimal to no effect outside of education. ${ }^{44}$ Nevertheless, due to their weak language, indirect support of religious education is possible. ${ }^{45}$

Blaine Amendments of moderate strength tend to prevent direct support of religious schools but the courts are left to interpret whether indirect support is allowed. ${ }^{46}$ This has created an uneven application of these laws because states with similar no-funding provision language have reached radically different conclusions regarding where the aid crosses over into unconstitutional territory. ${ }^{47}$ Nebraska is an example of a state with a moderate Blaine Amendment, which states "appropriation of public funds shall not be made to any school or institution of learning not owned or exclusively controlled by the state" and "[t]he state shall not accept money or property to be used for sectarian purposes." 48

Finally, the strongest Blaine Amendments block both direct and indirect aid for religious schools and tend to use broad language in order to encompass all religious institutions. ${ }^{49}$ Missouri's Blaine Amendment is an example of a strong Blaine Amendment. ${ }^{50}$ Its language bars any level of government from "fund[ing] . . . anything in aid of any religious creed,

41. Heytens, supra note 30, at 134 ("During the late nineteenth and early twentieth century, approximately thirty states wrote or amended their constitutions to include language substantially similar to that of the defeated federal Blaine Amendment. In fact, Congress required that several prospective states include such provisions in their constitutions as a condition for admission to the Union.").

42. DeForrest, supra note 4, at 577 ("One way to approach this material is to think about the state Blaine Amendments and their supporting case law on a continuum. On one end of the continuum are those states whose constitutional provisions and court rulings are narrowly cast to limit the restrictive scope of the Blaine Amendment. On the other end of the continuum are those states whose basic charters and judicial decisions cast a broad net over state government decisions to provide direct and indirect aid to religiously-affiliated schools. In the middle is a hodgepodge of states with Blaine provisions that permit some form of government aid to religious schools but prohibit overt funding.").

43. Id. at $577-578$.

44. Id.

45. See, e.g., Zelman v. Simmons-Harris, 565 U.S. 639, 662-63 (2002) (holding a state sponsored school voucher program did not violate the Establishment Clause).

46. DeForrest, supra note 4, at 578 .

47. Id. at 581 ("While it is clear that direct aid to overt sectarian education is prohibited by moderate Blaine Amendment language, there is some uncertainty among the states as to the boundary of that prohibition.").

48. NEB. CONST. art. VII, $\S 11$.

49. DeForrest, supra note 4 , at 587-88.

50. Id.; MO. CONST. art. IX, $\S 8$. 
church or sectarian purpose or . . . support[ing] or sustain[ing] any private or public school, academy, seminary, college, university, or other institution of learning controlled by any religious creed, church or sectarian denomination." $" 51$ Florida is another example of a state with a strong state Blaine Amendment. ${ }^{52}$ The Florida provision states, "[n]o revenue of the state or any political subdivision or agency thereof shall ever be taken from the public treasury directly or indirectly in aid of any church, sect, or religious denomination or in aid of any sectarian institution." $" 53$

\section{Kansas's Blaine Amendment}

When states adopted no-funding provisions for their state constitutions, Kansas joined in by adding a Blaine-influenced provision into the Kansas Constitution. ${ }^{54}$ As previously mentioned, some state Blaine Amendments are less restrictive because they only apply to the funding of public education. ${ }^{55}$ Kansas's Blaine Amendment falls into this category, however, Kansas's provision also occupies the middle of the spectrum of no-funding provision strength due to the provision's lack of clarity regarding whether indirect funding of religious schools is permissible. $^{56}$ When formed, Kansas went through three other constitutions before settling on the Wyandotte Constitution, which was approved by Congress. ${ }^{57}$ Before the finalized constitution, the other various proposals were created by abolitionists and pro-slavery settlers in Kansas. ${ }^{58}$

Out of the four proposed constitutions, the Leavenworth and Topeka versions contained the language of the modern Kansas Constitution regarding public financing of religious schools. ${ }^{59}$ Article VII, section 5 of

51. Mo. CONST. art. IX, § 8 .

52. FLA. CONST. art. I, § 3; id. art. IX, §6.

53. FLA. CONST. art. I, $\S 3$.

54. KAN. CONST. art. VI, $\S 8(c)(1859)$; Heytens, supra note 30, at 134 ("During the late nineteenth and early twentieth century, approximately thirty states wrote or amended their constitutions to include language substantially similar to that of the defeated federal Blaine Amendment.").

55. Fritz, supra note 17, at 47-48.

56. DeForrest, supra note 4, at 578.

57. Kan. Historical Soc'y, Kansas Constitutions, KANSAPEDIA (Aug. 2015), http://www.kshs.org/kansapedia/kansas-constitutions/16532.

58. HELLER, supra note 1, at 1-3.

59. TOPEKA CONST. of 1855, art. VII, § 2, http://www.kansasmemory.org/item/221061/text (" $[\mathrm{N}]$ o religious or other sect or sects shall ever have any exclusive right to, or control of, any part of the school funds of this State."); LEAVENWORTH CONST. of 1858, art. VII, $\S 5$, 
the Leavenworth Constitution reads, "No religious sect or sects shall ever have any right to, or control of, any part of the school funds of this State." 60 This language is identical to the modern constitution, the Wyandotte Constitution, which states, "No religious sect or sects shall ever control any part of the common-school or University funds of the State." Leavenworth Constitution particularly angered Catholic settlers in Kansas. ${ }^{62}$ This anger caused demonstrations in Leavenworth, displaying the growing tensions during the creation of Kansas's Constitutions. ${ }^{63}$

Interestingly, the creators of the Wyandotte Constitution used the Ohio Constitution as the basis for the Kansas Constitution. The Ohio Constitution Article 6, Section 2 reads:

The general assembly shall make such provisions, by taxation, or otherwise, as, with the income arising from the school trust fund, will secure a thorough and efficient system of common schools throughout the state; but no religious or other sect, or sects, shall ever have any exclusive right to, or control of, any part of the school funds of this state. $^{6}$

While sharing similar substance with Kansas's Blaine Amendment, Kansas's is much shorter; almost as if added as an afterthought. ${ }^{65}$ Though Kansas's language is different from Ohio's, Kansas may have inadvertently adopted the no-funding provision from Ohio's Constitution

http://www.kansasmemory.org/item/207410/text ("No religious sect or sects shall ever have any right to, or control of, any part of the school funds of this State.").

60. LEAVENWORTH CONST. of 1858, art. VII, $\S 5$.

61. WYANDOTTE CONST. of 1859, art. VI, $\S 8$, http://www.kansasmemory.org/item/90272/text.

62. Opponents of the Constitution, White Cloud KAN. CHIEF, May 13, 1858, at 2, https:/chroniclingamerica.loc.gov/lccn/sn82015486/1858-05-13/ed-1/ ("Leavenworth seems to be a great hotbed of opposition to the new Constitution, and [word unclear] demonstrations against it are held almost every night. We have heard that this opposition principally arises from the Catholics, not on account of negro suffrage, as they make believe, but on account of the following Section in the Article on Education: SECTION 5. No religious sect or sects shall ever have any right to, or control of, any part of the school funds of this State. This is no doubt the secret of the opposition of these bloodthirsty beings. - They want a part of the public school fund, for which the whole people are taxed, given to them, to support their sectarian schools, which are equivalent to nurseries of bigotry and houses of prostitution. This opposition alone should be an inducement for all good people to support the Constitution.").

63. Id.

64. OHIO CONST. art. VI, $\S 2$.

65. Though the reaction to the same provision in the previous constitution may indicate that it was more than an "afterthought." 
when borrowing the Ohio Constitution's language. ${ }^{66}$ Alternately, Kansas may have based their no-funding provision on Indiana's Constitution. ${ }^{67}$

During the $1880 \mathrm{~s}$, similar Blaine Amendments cropped up in numerous states located in the American West because Congress required states to have some form of no-funding provision in order to gain admission into the Union. ${ }^{6}$ States met this requirement by adopting various versions of the Blaine Amendment. ${ }^{69}$ However, as noted in the debate over the federal Blaine Amendment, these states still reserved space for generic Protestantism in the public sphere. ${ }^{70}$

The most applicable case interpreting Kansas's no-funding provision is Atchison, T. \& S.F.R. Co. v. City of Atchison. This 1892 Kansas Supreme Court case involved a taxpayer challenging the city of Atchison's tax increase to support religious schools. ${ }^{71}$ The court held that the city "had no power to impose a tax . . to aid private sectarian schools." A key fact for the court was that the schools would not be under public control it did not make sense for the public to fund the private school. ${ }^{73}$ Though not directly citing the Kansas no-funding provision, the case demonstrates the no-funding provision's clear restriction on direct aid for religious schools. Almost fifty years later in Wright v. School Dist. No. 27 of Woodson County, the Kansas Supreme Court reiterated this interpretation of the no-funding provision: "[the provision] is clear that no

66. Goldenziel, supra note 9, at 67 ("States also may have unwittingly adopted no-funding provisions when copying provisions from other states' constitutions.").

67. HELLER, supra note 1, at 52; see IND. CONST. art. I, § 6 ("No money shall be drawn from the treasury, for the benefit of any religious or theological institution.").

68. DeForrest, supra note 4, at 573 ("Most of the states that adopted Blaine language did so without pressure from the federal government. In other situations, however, Congress did compel the inclusion of Blaine Amendment language in some state constitutions, particularly for territories seeking admission to the Union as new states."); Goldenziel, supra note 9, at 66-67 ("Congress mandated similar [no-funding] provisions in the legislation enabling the statehood of North Dakota, South Dakota, Montana, Washington, Arizona, New Mexico, Utah, Idaho, and Oklahoma, and were later ratified as part of the constitutions of those states.").

69. DeForrest, supra note 4, at 573-74.

70. Id. at 575 ("Like Blaine and those who supported the Blaine Amendment, they believed in a robust religious presence in the public square, so long as that religious presence was compatible with broad Protestant devotional sentiment. This can be seen in the preamble to the [Washington] state constitution.").

71. Atchison, T. \& S.F.R. Co. v. City of Atchison, 28 P. 1000, 1000 (Kan. 1892).

72. Id. at 1001 .

73. Id. ("While it is argued that the public is benefited by the increase of schools and the spread of learning and knowledge, it is not contended that the colleges in question are under the supervision and control of the public, or that there is or could be any legislative authority to expend the public revenues for their support. The officers of the city had no power to impose a tax on the property of the citizens of Atchison to aid private, sectarian schools, or to promote private interests and enterprises."). 
religious sect . . can lawfully control our school funds."74 At issue was whether a school board could raise tax funds to support a sectarian school. $^{75}$ The petitioner tried to enjoin the school board and claimed that as a taxpayer he had standing to challenge the action. ${ }^{76}$ The Kansas Supreme Court held that the petitioner properly had standing to seek an injunction. ${ }^{77}$

As demonstrated above, Kansas has little case law regarding its nofunding provision. Outside of the plain reading of the provision, the only other source reflecting potential interpretations of the provision are Attorney General advisory opinions given to legislators contemplating forms of indirect student aid in Kansas. There are three opinions from 1994, 2000, and 2004, all written by Republican Attorney Generals, that shed some light on how Kansas governmental officials might interpret the provision. $^{78}$ The 1994 advisory opinion stated that the no-funding provision strictly prohibited any form of tax that would pay for or aid education in sectarian schools. ${ }^{79}$ This opinion discussed Kansas's limited case law on the issue before establishing, that because religious schools intertwine religious instruction and secular education, any support for the secular education side would inadvertently support the religious instruction. ${ }^{80}$ Thus, the 1994 advisory opinion advises that this type of indirect student aid would violate Kansas's no-funding provision. ${ }^{81}$

The next advisory opinion, issued in 2000, agreed with the 1994 opinion's conclusion but expanded on the private choice component of school vouchers. ${ }^{82}$ The opinion stated that even though the public funding was flowing to the schools indirectly by way of the parents' choices, this still had the effect of public money going to religious schools. ${ }^{83}$ Thus, this indirect support of religious schools was a clear violation of Kansas's nofunding provision. ${ }^{84}$

\footnotetext{
74. Wright v. School Dist. No. 27 of Woodson Cty., 99 P.2d 737, 738 (Kan. 1940).

75. Id.

76. Id.

77. Id.

78. Kan. Att'y Gen. Op. No. 94-37 (1994), http://ksag.washburnlaw.edu/opinions/1994/1994037.htm; Kan. Att'y Gen. Op. No. 2000-32 (2000), http://ksag.washburnlaw.edu/opinions/2000/2000032.htm; Kan. Att'y Gen. Op. No. 2004-5 (2004), http://ksag.washburnlaw.edu/opinions/2004/2004005.htm.

79. Kan. Att'y Gen. Op. No. 94-37 (citing Atchison T. \& S.F.R. Co., 28 P. 1000, Billard v. Bd. of Educ., 76 P. 422 (1904), and Wright, 99 P.2d 737).

80. Id.

81. Id.

82. Kan. Att'y Gen. Op. No. 2000-32.

83. Id.

84. Id.
} 
Finally, the most recent advisory opinion, issued in 2004, came to a very different conclusion than the others. The Kansas Attorney General determined that Kansas's no-funding provision did not prevent governmental aid to religious schools as long as the aid was for the students. ${ }^{85}$ The Attorney General noted that the legislative history of the 1966 Constitutional amendment states that the no-funding provision would not "prohibit the appropriation of public funds to indirectly benefit private institutions." ${ }^{\prime 6}$ Thus, funding to private schools is permissible as long as the funding benefitted the child and not the school. ${ }^{87}$ In further analyzing the effect on a voucher program, the Attorney General noted that other states with similar no-funding provisions have struck down voucher programs. ${ }^{88}$ However, Kansas's voucher program is modeled after Ohio's program, which survived scrutiny in the Zelman cases, and thus Kansas's voucher program likely complies with Kansas's no-funding provision. ${ }^{89}$

As these advisory opinions exemplify, there is no clear understanding of Kansas's no-funding provision or how it would be applied in cases of indirect funding. This same confusion is evident in other states as well. ${ }^{90}$ It would greatly benefit both Kansas and other states for the Supreme Court to explain when these no-funding provisions cross the line into violating Free Exercise Rights. Though Trinity Lutheran gives us a partial answer, it is time for the courts to flesh out a full answer.

\section{B. Zelman, Locke, \& Trinity Lutheran: Foundational Cases}

The Supreme Court has dealt with numerous religious freedom cases, however, three cases addressing state no-funding provisions stand out. Zelman v. Simmons-Harris, Locke v. Davey, and Trinity Lutheran v. Comer have all profoundly impacted this topic, and together they formulate clear guidance on how the courts should resolve conflicts between no-funding provisions and religious freedom.

85. Kan. Att'y Gen. Op. No. 2004-5 (2004), http://ksag.washburnlaw.edu/opinions/2004/2004005.htm.

86. Id. (quoting Kan. Legis. Council, The Education Amendment to the Kansas Constitution, Pub. No. 256, at 36 (Dec. 1965)).

87. Kan. Att'y Gen. Op. No. 2004-5.

88. Id.

89. Id.

90. See Trinity Lutheran Church of Columbia, Inc. v. Comer, 137 S. Ct. 2012, 2015 (2017) (addressing Missouri's no-funding provision); Colo. Taxpayers for Pub. Educ. v. Douglas Cnty. Sch. Dist., 351 P.3d 461, 469-76 (Colo. 2015), vacated, 137 S. Ct. 2327 (2017); Weinbaum v. Skandera, 367 P.3d 838, 846 (N.M. 2015), vacated sub. nom., N.M. Ass'n of Non-Pub. Schs. v. Moses, 137 S. Ct. 2325 (2017). 


\section{Zelman v. Simmons-Harris}

Before Trinity Lutheran, Zelman v. Simmons-Harris was the prominent religious freedom case involving public funding of religious schools. In this case, Ohio established a program that gave vouchers to students in poorly performing public schools in the Cleveland public school district. ${ }^{91}$ These students could then use the vouchers at any school, public or private, that participated in the state program. ${ }^{92}$ Plaintiffs originally challenged this program on a variety of grounds, but two were key: first, that the program violated a variety of Ohio Constitutional provisions, including Ohio's no-funding provision, and second, that the program violated the Establishment Clause of the United States Constitution. ${ }^{93}$ The issue regarding the violation of the Ohio Constitution was sorted before the state supreme court where the Ohio Supreme Court held that the provision did not violate their no-funding provision. ${ }^{94}$ Ohio previously established that indirect aid did not give religious schools "an exclusive right to, or control of, any part of the school funds of this state." However, the Ohio Supreme Court found some procedural defects in the Ohio statute. ${ }^{96}$ The Ohio Legislature subsequently fixed this defect and the statute was then challenged a second time, this time in federal court which led to Zelman v. Simmons-Harris.

This left only the Establishment Clause question for the United States Supreme Court to answer. The Court held that the program did not violate the Establishment Clause because it did not have the effect of advancing religion. ${ }^{97}$ In coming to this conclusion, the Court relied on the distinction between direct and indirect aid. ${ }^{98}$ The Court noted that its decisions have consistently drawn a "distinction between government programs that provide aid directly to religious schools, and programs of true private choice." 99 Since Ohio's statute relied on individual choice for the state

\footnotetext{
91. Zelman v. Simmons-Harris, 536 U.S. 639, 644-45 (2002).

92. Id. at 645 .

93. Simmons-Harris v. Goff, 711 N.E.2d 203, 207 (Ohio 1999).

94. Id. at 212 .

95. Id. (quoting Protestants \& Other Ams. United for Separation of Church \& State v. Essex, 275 N.E.2d 603, 608 (Ohio 1971)).

96. Simmons-Harris v. Goff, 711 N.E.2d 203, 214-16 (Ohio 1999) (holding that the creation of a substantive program in a general appropriations bill violated Ohio's constitutional one-subject rule).

97. Zelman v. Simmons-Harris, 536 U.S. 639, 662-63 (2002).

98. Id. at 649-53 ("Three times we have confronted Establishment Clause challenges to neutral government programs that provide aid directly to a broad class of individuals, who, in turn, direct the aid to religious schools or institutions of their own choosing. Three times we have rejected such challenges").

99. Id. at 649 (citations omitted).
} 
money to go to religious organizations the Court would have to focus on "whether beneficiaries of indirect aid ha[d] a genuine choice among religious and nonreligious organizations."100 Because the Ohio program gave monetary aid to students who then had the choice to give that money to religious private schools, Ohio's program did not violate the Establishment Clause. ${ }^{101}$

In her concurring opinion, Justice O'Connor separated this case from past cases that found indirect aid unconstitutional by noting that in this case, the money reached these religious schools through pure private choice. ${ }^{102}$ She also noted, religious institutions are already awarded money from the government through tax breaks and tax credits. ${ }^{103}$ Due to this, the support Cleveland offered religious schools through their voucher program, was not "atypical of existing government programs."104 Thus, the Court ruled that the voucher program did not run afoul of the Establishment Clause. ${ }^{105}$ Justice O'Connor's concurrence further explained how the Lemon test should apply to indirect funding cases, specifically, whether the program is neutral and if the indirect funding was only due to private choice. ${ }^{106}$

The dissenting justices seemed very wary about the effect of Zelman on existing precedent. ${ }^{107}$ Justice Souter's dissent interpreted the Ohio law as unconstitutional under an Establishment Clause analysis. ${ }^{108}$ Justice Souter pointed to prior Supreme Court precedent which seemed to indicate that any tax supporting religious institutions that teach religion was unconstitutional. ${ }^{109}$ Justice Breyer authored a separate dissent stating his concern that the government's involvement in religious education would cause potential social conflict. ${ }^{110} \mathrm{He}$ based this characterization largely

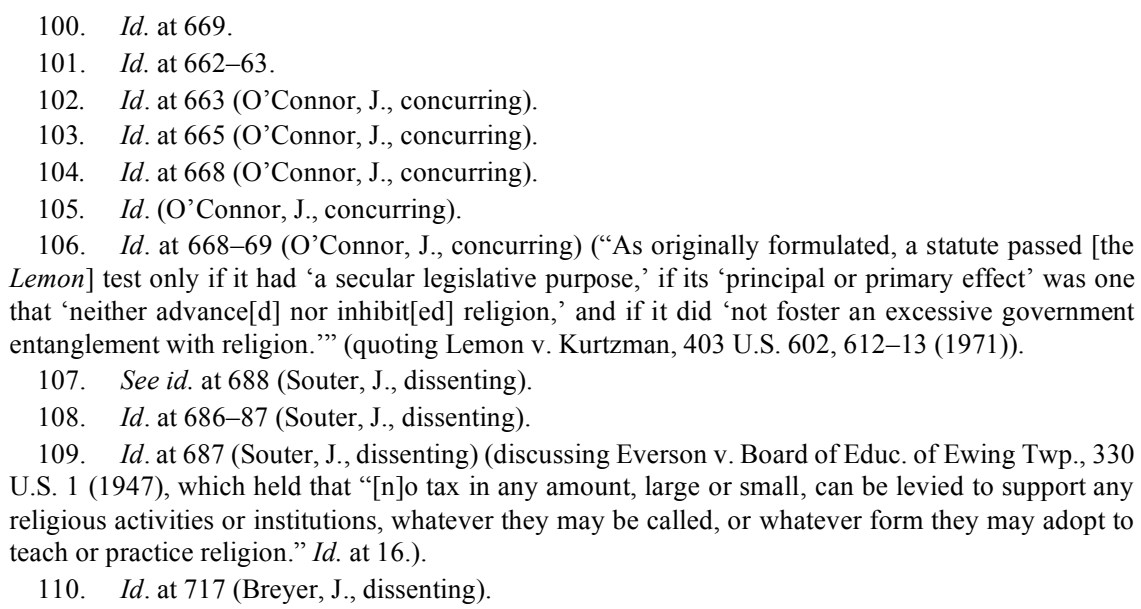


upon the same history and motivation behind the Blaine Amendment's creation. ${ }^{11}$ In Justice Breyer's opinion, applying the Establishment Clause to the states remedied this social conflict. ${ }^{112}$ Justice Breyer tied this together by stating that the allowance of publicly funded school voucher programs would lead back to religious conflict. ${ }^{113}$

\section{Locke v. Davey}

While providing a clear holding, Zelman failed to clarify the Supreme Court's intention regarding these no-funding provisions as evidenced by another case involving a state no-funding provision, Locke v. Davey. ${ }^{114}$ This case involved Washington's Promise Scholarship Program which helped gifted high school students pay for college. ${ }^{115}$ There were some caveats to this support, however. Washington's strict no-funding provision prohibited the state from paying for any scholarships for students to study theology. ${ }^{116}$ Davey challenged this provision as unconstitutional when he was denied from using his scholarship to study theology. ${ }^{117}$ The district court granted summary judgment in favor of the state while the Ninth Circuit Court of Appeals held that Washington had unfairly discriminated against religion and had no compelling reason to deny the funding of scholarships for religious training under their program. ${ }^{118}$ The Ninth Circuit viewed the Washington law as treating religious students different from non-religious students when it denied funding for Davey's religious education. ${ }^{119}$

In Locke, the Supreme Court held that Washington could fund scholarships for students who desired to pursue a degree in theology under the United States Constitution. ${ }^{120}$ However, Washington courts had interpreted Washington's constitution as prohibiting indirect funding of religious purposes. ${ }^{121}$ This ability for some actions to be "permitted by

\footnotetext{
111. Id. at 720-21 (Breyer, J., dissenting); see also supra notes 31-39.

112. Id. at 721-22 (Breyer, J., dissenting).

113. Id. at 727 (Breyer, J., dissenting) ("[T]he majority's analysis here appears to permit a considerable shift of taxpayer dollars from public secular schools to private religious schools. That fact, combined with the use to which these dollars will be put, exacerbates the conflict problem.").

114. Locke v. Davey, 540 U.S. 712,719 (2004).

115. Id. at 715 .

116. Id. at 716 .

117. Id. at $717-18$

118. Id. at 718 .

119. Id.

120. Id.

121. Id. at 719 .
} 
the Establishment Clause but not required by the Free Exercise Clause" is called finding "room for play in the joints." 122 The Court did not find any animosity in Washington's law and did not find it unconstitutional. ${ }^{123}$ Further, the majority noted that the students could use the scholarships at religious schools and even use the money to take religious classes at either a public or religious school. ${ }^{124}$ The only thing students could not use the money for was to pursue a degree in theology. ${ }^{125}$ At the end of the majority opinion, the Court acknowledged the inherent difficulty of handling these types of topics. ${ }^{126}$

In his dissent, Justice Scalia pointed to the fact that the state had made a benefit available to the public. ${ }^{127}$ Yet Washington withheld the benefit on the basis of religion. ${ }^{128}$

When the State makes a public benefit generally available, that benefit becomes part of the baseline against which burdens on religion are measured; and when the State withholds that benefit from some individuals solely on the basis of religion, it violates the Free Exercise Clause no less than if it had imposed a special tax. ${ }^{129}$

This argument proved helpful as it later helped bolster the Court's decision in Trinity Lutheran. ${ }^{130}$

Kansas provides another example of the ambiguity of Blaine Amendments. Though Kansas has one of the "weaker" state Blaine Amendments, the state government has articulated different opinions regarding its impact on topics such as school choice. ${ }^{131}$ The state government's opinion on the no-funding provision's impact relies on the

\footnotetext{
122. Id. at $718-19$.

123. Id. at 725 .

124. Id. at 724 ("The program permits students to attend pervasively religious schools, so long as they are accredited.").

125. Id. at 715 .

126. Id. at 725 .

127. Id. at 726-27 (Scalia, J., dissenting).

128. Id. (Scalia, J., dissenting).

129. Id. (Scalia, J., dissenting).

130. See Trinity Lutheran Church of Columbia, Inc. v. Comer, 137 S. Ct. 2012, 2021 (2012) ("The Department's policy expressly discriminates against otherwise eligible recipients by disqualifying them from a public benefit solely because of their religious character.").

131. Compare Kan. Att'y Gen. Op. No. $94-37$ (1994), http://ksag.washburnlaw.edu/opinions/ 1994/1994-037.htm (advising that Kansas's no-funding provision prevents religious schools from receiving indirect aid from the 1994 proposed Kansas voucher program), and Kan. Att'y Gen. Op. No. 2000-32 (2000), http://ksag.washburnlaw.edu/opinions/2000/2000-032.htm (advising that Kansas's no-funding provision prevents indirect funding of religious schools such as voucher programs), with Kan. Att'y Gen. Op. No. 2004-5 (2004), http://ksag.washburnlaw.edu/opinions/2004/2004-005.htm (advising that indirect funding of religious schools would not violate Kansas's no-funding provision).
} 
administration. ${ }^{132}$ Thus, the Kansas Attorney General can give radically different answers to the same question. ${ }^{133}$ Under one administration, the no-funding provision in Kansas's constitution clearly could show that the state cannot give school vouchers for religious schools, while future administrations could argue that the same provision provides no obstacle to such funding. This resulting whiplash demonstrates the dire need for the United States Supreme Court to address and clarify this topic. Trinity Lutheran v. Comer was the latest case to offer the Court this opportunity.

\section{Trinity Lutheran Church of Columbia, Inc. v. Comer}

The Trinity Lutheran cases arose from a simple Missouri governmental program, the Scrap Tire Program. ${ }^{134}$ This program recycles old tires into playground surfaces, usually resulting in a safer environment for kids playing on the equipment. ${ }^{135}$ Trinity Lutheran Church applied for the program in 2012 for their Child Learning Center, a preschool and daycare center. ${ }^{136}$ When Missouri was analyzing the potential candidates for the Scrap Tire Program, Trinity Lutheran was one of the top candidates, coming in fifth out of the forty-four applications. ${ }^{137}$ However, Missouri denied the application due to a conflict with Article I, Section 7 of the Missouri Constitution, which clearly states, "[t]hat no money shall ever be taken from the public treasury, directly or indirectly, in aid of any church." ${ }^{138}$ Since the program would serve as public funding of a religious institution, the State of Missouri believed their hands were tied in the denial of the application. ${ }^{139}$ Subsequently, Trinity Lutheran brought a lawsuit in Federal District Court which the court dismissed, finding that the Free Exercise Clause "does not prohibit withholding an affirmative benefit on account of religion." "The Eighth Circuit affirmed this dismissal. ${ }^{141}$ Both the District Court and the Eighth Circuit Court held that the Supreme Court's decision in Locke was persuasive regarding this issue. $^{142}$

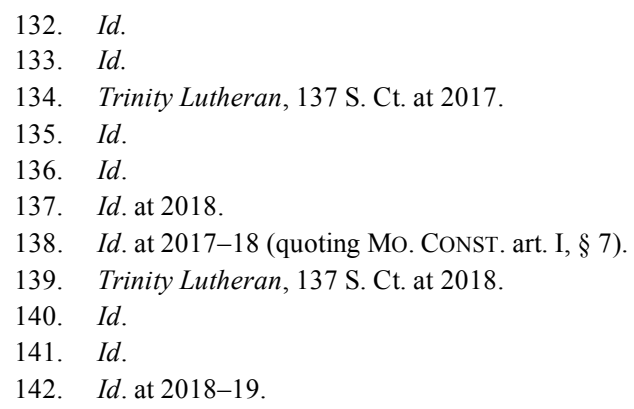


Leading up to the oral argument in the Supreme Court, speculation that Trinity Lutheran $v$. Comer could end up a landmark case for religious freedom abounded. ${ }^{143}$ The speculation turned out to be correct. With a seven to two majority, the Court ruled that the State of Missouri could not restrict Trinity Lutheran from a publicly funded program solely on the basis of their religious affiliation. ${ }^{144}$ The Supreme Court pointed out that the Missouri program seemed to give Trinity Lutheran Church a choice: Trinity Lutheran "may participate in an otherwise available benefit program or remain a religious institution."145 The Court felt like this crossed a line. Because Missouri forced the Church to choose between disavowing its religious affiliation and receiving a public funding or staying true to its convictions but receiving nothing, the statute was a clear violation of the Free Exercise Clause. ${ }^{146}$ The majority drew its rationale from the Locke decision, but distinguished their decision from Locke by explaining that the scholarship program in Locke "did not "require students to choose between their religious beliefs and receiving a government benefit." "147 Due to its groundbreaking nature, the majority attempted to head off the use of this case as precedent in other religious freedom cases by inserting a footnote which limited the decision to factually similar situations. ${ }^{148}$ Concluding the majority opinion, Chief Justice Roberts expressed the view of the majority with a quote:

If, on account of my religious faith, I am subjected to disqualifications, from which others are free, ... I cannot but consider myself a persecuted man. ... An odious exclusion from any of the benefits common to the rest of my fellow-citizens, is a persecution, differing only in degree, but of a nature equally unjustifiable with that, whose instruments are chains and torture. ${ }^{149}$

143. Emma Green, The Supreme Court Considers Whether Churches Should Get Taxpayer Dollars, ATLANTIC (Apr. 19, 2017), https://www.theatlantic.com/politics/archive/2017/04/trinitylutheran $/ 523542 \%$.

144. Trinity Lutheran, 137 S. Ct. at 2025 ("But the exclusion of Trinity Lutheran from a public benefit for which it is otherwise qualified, solely because it is a church, is odious to our Constitution all the same, and cannot stand.").

145. Id. at 2021-22.

146. Id. at 2024 .

147. Id. at 2023 (quoting Locke v. Davey, 540 U.S. 712, 720-21 (2004)).

148. Id. at $2024 \mathrm{n} .3$ ("This case involves express discrimination based on religious identity with respect to playground resurfacing. We do not address religious uses of funding or other forms of discrimination.").

149. Id. at 2024 (quoting H. M. Brackenridge, Speech Delivered in the House of Delegates of Maryland (Dec. 1818), in H. BrackenRidge, W.G.D. WORTHINGTON, \& JOHN S. TYSON, SPEECHES ON THE JEW BILL IN THE HOUSE OF DELEGATES OF MARYLAND 64 (1829)). 
Though agreeing with the majority's result, Justice Gorsuch found this argument unpersuasive. Justice Gorsuch indicated that the general principles discussed in Trinity Lutheran were applicable in a wider area of law. "[T] he general principles here do not permit discrimination against religious exercise - whether on the playground or anywhere else."150 Justice Gorsuch also pointed out flaws in the majority's reasoning. $\mathrm{He}$ criticized the distinction between religious status and religious use, outlined in their discussion of Locke and relied on to make their decision. ${ }^{151}$ As mentioned above, the Court in Locke found Washington's discrimination constitutional because it only discriminated against the religious use (Davey's pursuit of a theology degree) and not religious status (Davey's Christianity). Discrimination based on religious status violated the Free Exercise Clause, but states could discriminate under certain situations. ${ }^{152}$ Justice Gorsuch pointed to how difficult it is to apply this standard, stating:

The distinction blurs in much the same way the line between acts and omissions can blur when stared at too long, leaving us to ask (for example) whether the man who drowns by awaiting the incoming tide does so by act (coming upon the sea) or omission (allowing the sea to come upon him). ${ }^{153}$

The Court's failure to distinguish between religion status and religious use could have key ramifications in the application of the state Blaine Amendments. Many state courts had used this distinction to uphold their state no-funding provision's applicability. If the majority's distinction in Trinity Lutheran is incorrect, as Justice Gorsuch points out, the application of these no-funding provisions in broader religious freedom issues could be unconstitutional. ${ }^{154}$ Further, the failure of the religious status/religious use distinction leaves the religious freedom realm without an adequate test. As I will explain later in this Comment, courts can address this caveat by using an indirect/direct public funding distinction instead of the Trinity Lutheran majority's religious use/religious status distinction.

Not failing to pull any punches, in her dissent, Justice Sotomayor worries that this distinction between direct and indirect funding creates more than just a landmark case for religious freedom. ${ }^{155}$ She contends that

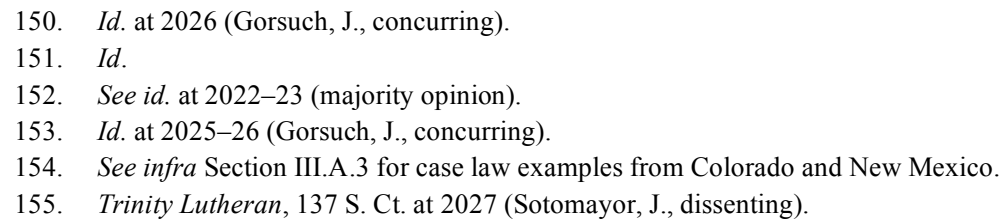


the Trinity Lutheran majority obliterated past precedent and upended the purpose of the Establishment Clause of the First Amendment. ${ }^{156}$ Her core critique of the majority's opinion is that the Court did not factor in the purpose of Trinity Lutheran's playground. ${ }^{157}$ She points to the fact that on Trinity Lutheran's website, the church states that the purpose of the school and playground were inherently religious. ${ }^{158}$ However, she acknowledges that the Court's prior cases show that some "government funding of religious institutions to be consistent with the Establishment Clause. But the funding in those cases came with assurances that public funds would not be used for religious activity, despite the religious nature of the institution." 159 Justice Sotomayor ends her dissent voicing concern that the Court's ruling in Trinity Lutheran will destroy the various Blaine Amendments in the states. ${ }^{160}$

\section{ANALYSIS}

Trinity Lutheran may have added a spark in an already wildfire-prone area of law. This Comment will focus on several topics most impacted by the Court's decision. First, the impact to Kansas's and other states' Blaine Amendments; second, the impact on the doctrine of separation of church and state; and third, the policy impacts on the school-choice movement.

\section{A. Implications for State-No Funding Provisions}

The worries Justice Sotomayor expressed in her dissent may end up justified. After the Zelman v. Simmons-Harris decision, the strict state Blaine Amendments were one of the most effective methods for state courts to keep public money away from religious private schools. ${ }^{161}$ Religious freedom advocates recently started to target these no-funding

\footnotetext{
156. Id. at 2029.

157. Id.

158. Id. at 2027

159. Id. at 2029 .

160. Id. at 2041 ("The constitutional provisions of thirty-nine States—all but invalidated todaythe weighty interests they protect, and the history they draw on deserve more than this judicial brush aside.").

161. DeForrest, supra note 4, at 602 ("State courts in the twentieth century, with a few exceptions already discussed, rigorously enforced Blaine language to preclude direct, and in many cases indirect, aid and assistance to religious schools or those who wish to attend such schools."); but see Goldenziel, supra note 9, at 99 ("Given the array of judicial options for circumventing, invalidating, or even ignoring state no-funding provisions, the federal Blaine Amendment simply cannot be blamed for halting school choice in the states. The name of Blaine seems mainly used in vain.").
} 
provisions and Trinity Lutheran moved them further in the crosshairs. ${ }^{162}$ The Establishment Clause's inability to prevent the flow of indirect aid to religious institutions has left only the Blaine Amendments in the way of state indirect aid to these institutions. While there is not currently a challenge to Kansas's Blaine Amendment, litigation is almost certain, and under the Trinity Lutheran and Zelman holdings, its Blaine Amendment is likely unconstitutional in specific applications.

\section{Impact on Article 6, Section 6(c) of the Kansas Constitution}

As previously mentioned, Kansas's Blaine Amendment is unique in its relative brevity and limited focus on educational funding. ${ }^{163}$ Therefore, analysis of its applicability is only necessary for a singular realmeducational funding. Kansas's scarce judicial precedent addressing this constitutional provision would likely cause courts to treat this issue as a case of first-impression making any prediction on how the Kansas Supreme Court would rule pure conjecture. With no current litigation involving this provision, there is no way to know whether the Kansas Supreme Court would interpret the Kansas no-funding provision flexibly like Ohio, or more strictly like Colorado and Missouri. ${ }^{164}$ However, various Kansas Attorneys General opinion regarding whether a school voucher system which includes religious schools would violate the constitutional provision provides some insight, however, those opinions only look at indirect funding options. ${ }^{165}$

As with all religious freedom cases, a balance must be maintained between the Free Exercise and Establishment interests. This test is typically referred to as finding "room for play in the joints."166 Trinity Lutheran established that a state cannot withhold a public benefit from a

\footnotetext{
162. See e.g., Locke v. Davey, 540 U.S. 712 (2004); Bush v. Holmes, 919 So. $2 d 392$ (Fla. 2006).

163. See supra Section II.A.4.

164. Ohio's Supreme Court held that the state's no-funding provision did not block indirect aid in Protestants \& Other Ams. United for Separation of Church \& State v. Essex, 275 N.E.2d 603 (Ohio 1971), whereas Colorado's Supreme Court found that indirect aid violated Colorado's no-funding provisions in Taxpayers for Pub. Educ. v. Douglas Cty. Sch. Dist., 351 P.3d 461 (Colo. 2015), vacated, 137 S. Ct. 2325 (2017) (remanded for further consideration).

165. See Kan. Att'y Gen. Op. No. 94-37 (1994), http://ksag.washburnlaw.edu/opinions/1994/ 1994-037.htm (advising that Kansas's no-funding provision prevents religious schools from receiving indirect aid from the 1994 proposed Kansas voucher program); Kan. Att'y Gen. Op. No. 2000-32 (2000), http://ksag.washburnlaw.edu/opinions/2000/2000-032.htm (advising that Kansas's nofunding provision prevents indirect funding of religious schools such as voucher programs); Kan. Att'y Gen. Op. No. 2004-5 (2004), http://ksag.washburnlaw.edu/opinions/2004/2004-005.htm (advising that indirect funding of religious schools would not violate Kansas's no-funding provision). 166. Trinity Lutheran Church of Columbia, Inc. v. Comer, 137 S. Ct. 2012, 2036 (2017).
} 
private institution on the basis of religious affiliation. ${ }^{167}$ Withholding publicly available money from religious schools impacts their Free Exercise rights because it restricts public education funding on the basis of their religious affiliation. The Trinity Lutheran majority attempted to parry this argument by distinguishing between religious status and religious use. ${ }^{168}$ As seen in Locke, states can restrict public funds from private individuals when used to support religious use. ${ }^{169}$ The refusal to fund religious schools may constitute religious discrimination under the Free Exercise Clause. However, because religious schools teach religious materials, this type of direct funding of religious use is prohibited under Locke and Trinity Lutheran.

Justice Gorsuch's concurring opinion in Trinity Lutheran seems to refute this argument. Justice Gorsuch pointed out that religious status and religious use are difficult to separate. ${ }^{170}$ Any discrimination on the basis of religious status could be viewed as discrimination on religious use, rendering the test ineffective. Thus, this test would be useless in any religious freedom analysis. Justice Gorsuch distinguishes Locke and Trinity Lutheran because the Court based its Locke decision on the long tradition of preventing public funding of training for clergy and this tradition had no effect on the Trinity Lutheran case. ${ }^{171}$ Courts can use the same principle in the school financing discussion. If a party can prove that there has been a tradition of the government funding religious schools in America, any future case over public funding of religious schools can be distinguished from Locke, just as Trinity Lutheran was distinguishable. In contrast, if a party shows that there is a history of not funding religious schools then the case may look more like Locke than Trinity Lutheran.

\section{Hypothetical Kansas Case Involving the No-Funding Provision}

Kansas's current funding scheme is likely still constitutional, but if Kansas follows the examples of other states and sets up a school choice program, Kansas's constitutional provision may conflict with the Free Exercise Clause. A hypothetical state voucher program that reimburses

\footnotetext{
167. Id. at 2024 .

168. Id. at 2025 .

169. Id. at 2023 (discussing Locke, the Trinity Lutheran Court noted that "Davey was not denied a scholarship because of who he was; he was denied a scholarship because of what he proposed to do - use the funds to prepare for the ministry").

170. Id. at 2025-26 (Gorsuch, J., concurring).

171. Id. at 2026 (Gorsuch, J., concurring) ("If that case can be correct and distinguished, it seems it might be only because of the opinion's claim of a long tradition against the use of public funds for training of the clergy, a tradition the Court correctly explains has no analogue here.").
} 
parents for sending their children to private schools, but to comply with the Kansas Constitution, only reimburses parents who send their children to secular private schools would inevitably lead to a lawsuit challenging the voucher program on the grounds of the Free Exercise Clause. There, the Kansas Supreme Court would have to apply Trinity Lutheran.

Under the Trinity Lutheran majority's analysis, Kansas' Blaine Amendment would be unconstitutional. Any analysis of Kansas's program would require Kansas to display a state interest of the "highest order" in order to justify their policy. ${ }^{172}$ The hypothetical program would create a public benefit that religious schools cannot reap due to their religious nature. In order to qualify for public funds, they would need to acquiesce their religious nature. Whether you accept the majority's status/use distinction or Justice Gorsuch's argument that status and use both fall under the Free Exercise Clause, forcing religious schools to become "secular" in order to receive public funding seemingly violates Trinity Lutheran's holding. Further, because the Free Exercise Clause intends to protect against unequal treatment, blatantly excluding religious schools solely due to their religious nature clearly violate the First Amendment. However, this does not mean that public money must go toward supporting the religious part of religious education. Additionally, it is unclear how far the Court would be willing to apply Trinity Lutheran in cases involving the direct funding of religious schools. While the analysis of Kansas's Blaine Amendment under the Trinity Lutheran holding would most likely find the Blaine Amendment unconstitutional, any public funding of religious schools would still have Establishment Clause concerns.

When addressing Establishment Clause concerns the Court has noted that "achieving greater separation of church and state than is already ensured under the Establishment Clause of the Federal Constitution-is limited by the Free Exercise Clause." 173 Typically the Court applies the infamous Lemon test to gauge Establishment Clause concerns. ${ }^{174}$ The Lemon test is a three prong test which looks to see whether the statute has a secular purpose, whether the primary purpose of the statute advances or inhibits religions, and whether the statute creates excessive entanglement

\footnotetext{
172. Id. at 2019 (quoting McDaniel v. Paty, 435 U.S. 618, 628 (1978)).

173. Widmar v. Vincent, 454 U.S. 263, 276 (1981).

174. Justice Scalia was a noted critic of the "infamous" Lemon test, likening the test to a "ghoul in a late-night horror movie that repeatedly sits up in its grave and shuffles abroad, after being repeatedly killed and buried." Lamb's Chapel v. Ctr. Moriches Union Free School Dist., 508 U.S. 384, 398 (1993) (Scalia, J., concurring).
} 
between the state and religion. ${ }^{175}$ For a statute or policy to pass the test, it must satisfy all three prongs. ${ }^{176}$ Fortunately, Zelman provides clear precedent regarding whether indirect funding passes the Lemon Test. ${ }^{177}$ In Zelman, the Supreme Court held that public money could go toward religious institutions without violating the Establishment Clause, as long as that money would not "have the effect of advancing religion." 178 In addition, the Court applies a less stringent test for indirect public aid which considers two factors:

[F]irst, whether the program administers aid in a neutral fashion, without differentiation based on the religious status of beneficiaries or providers of services; second, and more importantly, whether beneficiaries of indirect aid have a genuine choice among religious and nonreligious organizations when determining the organization to which they will direct that aid. ${ }^{179}$

In other words, the money must have a secular purpose.

If Kansas's Blaine Amendment is found unconstitutional, the state can and must remedy this by clarifying and strengthening the secular/sacred divide. Under current Supreme Court precedent, public education funding can go to religious schools but not towards supporting their religious purpose. ${ }^{180}$ This distinction is normally accomplished by the Supreme Court's direct/indirect aid test. ${ }^{181}$ Direct aid violates the Establishment Clause, while indirect aid is constitutional. ${ }^{182}$ This distinction is necessary, yet its current application diminishes religious free exercise. Allowing public funds to reach into religious schools and help fund the secular aspect of their education helps rectify this diminishing aspect of the secular/sacred divide. This is a distinction that the Court has headed toward and will likely adopt when a school voucher/tax credit case comes before the Court. So, while Kansas's direct support of religious schools is still unconstitutional due to the Establishment Clause and Kansas's nofunding provision, indirect aid could be constitutional under recent Supreme Court precedent.

\footnotetext{
175. See Zelman v. Simmons-Harris, 536 U.S. 639, 668 (2002)

176. Id.

177. Id. at 668-69.

178. Tilton v. Richardson, 403 U.S. 672, 683 (1971).

179. Zelman, 536 U.S. at 669 .

180. Id. at 652 (" $[\mathrm{W}]$ here a government aid program is neutral with respect to religion, and provides assistance directly to a broad class of citizens who, in turn, direct government aid to religious schools wholly as a result of their own genuine and independent private choice, the program is not readily subject to challenge under the Establishment Clause.").

181. Id. at 649 .

182. Id.
} 
Essentially, there are two ways to understand Kansas's no-funding provision. First, Kansas courts could interpret the provision to not apply to indirect aid, which would seem to unconstitutionally infringe on religious school's Free Exercise rights under Trinity Lutheran and Zelman. Second, Kansas courts could interpret the no-funding provision as only applicable to direct funding cases. This interpretation would be constitutionally sound unless the direct funding applied to a publicly available program as in Trinity Lutheran. Because both interpretations lead to the same conclusion, Kansas courts should take the steps necessary to distinguish between cases involving direct funding and cases involving indirect funding. Doing so would clear up potential confusion regarding the provision's application and give courts clear guidance for when a statute violates Kansas's no-funding provision.

3. What Does the Future Hold? An Analysis of Upcoming No-Funding Provision Cases

Due to Kansas's lack of current litigation on this issue, a recent Colorado case may help provide some insight on interactions between Trinity Lutheran and state no-funding provisions. In Taxpayers for Public Education v. Douglas County School District, the Colorado Supreme Court found that a program awarding scholarships to help students pay their tuition violated Article IX, Section 7 of the Colorado ConstitutionColorado's Blaine Amendment. The court rested its decision purely upon the language in Section $7 .{ }^{183}$

The court's reasoning bore a striking resemblance to the defense of Missouri's actions in Trinity Lutheran. The school district argued that the court should follow the Supreme Court's precedent in Zelman v. SimmonsHarris due to the similarities between Ohio's program and Colorado's. ${ }^{184}$ However, the court found the argument unpersuasive because Colorado's laws were "far more restrictive than the Establishment Clause regarding governmental aid to religion." 185 The school district appealed to the United States Supreme Court, where the Court granted certiorari, vacated the judgment, and remanded the case to the Colorado Supreme Court to evaluate its previous decision in light of Trinity Lutheran. ${ }^{186}$ This would

\footnotetext{
183. Taxpayers for Pub. Educ. v. Douglas Cnty. Sch. Dist., 351 P.3d. 461, 470 (Colo. 2015).

184. Id. at 474 .

185. Id.

186. Colo. State Bd. of Educ. v. Taxpayers for Pub. Educ., 137 S. Ct. 2325 (2017) (mem.); Supreme Court Orders New Look at Colorado School Voucher Program, THE DENVER POST (June 27, 2017), http://www.denverpost.com/2017/06/27/colorado-schools-voucher-program/.
} 
have been an interesting test case for future school-choice litigation, unfortunately, a new school board rescinded the program at issue, and the Colorado Supreme Court dismissed the case as moot. ${ }^{187}$ In its past decision, the Colorado Supreme Court affirmed that this was a public program that gave public money indirectly to both religious and secular private schools. ${ }^{188}$ The Colorado Supreme Court's past holding allowing the state to discriminate against religious schools solely due to their religious nature may be in danger after Trinity Lutheran. Restricting these types of programs will be nearly impossible post-Trinity Lutheran, potentially opening the flood-gates to litigation involving similarly structured programs.

If the remand had led to a decision, the remand would have likely ended in favor of the school choice program because the Colorado Supreme Court based its original decision on Colorado's no-funding provision. Limiting the program to only secular schools would violate Trinity Lutheran's precedent and Zelman's finding of indirect aid to religious schools as constitutional under the Establishment Clause.

In addition to the Colorado case, other states also face Trinity Lutheran upending prior decisions. When the Supreme Court remanded Taxpayers for Public Education, it also remanded a New Mexico case, Weinbaum $v$. Skandera. ${ }^{189}$ The case revolved around the state's Instructional Material Law. ${ }^{190}$ The law allowed the state to give certain public and private schools money to buy textbooks approved by New Mexico. ${ }^{191}$ This included support for religious private schools. ${ }^{192}$ The petitioners challenged this support because New Mexico's Constitution prevents public funding for any religious educational institution. ${ }^{193}$ Both the state district court and the court of appeals found in the favor of the state. ${ }^{194}$ The New Mexico Supreme Court, however, reversed and held that the

187. Taxpayers for Pub. Educ. v. Douglas Cnty. Sch. Dist., No. 2013SC233, 2018 WL 1023945, at *1 (Colo. Jan. 25, 2018); Michael Roberts, Douglas County School Board Kills Controversial Voucher Program, WESTWORD (Dec. 5, 2017 7:45 AM), http://www.westword.com/news/douglascounty-school-board-votes-to-end-voucher-program-9756554.

188. Taxpayers for Pub. Educ., 351 P.3d at 470 ("To be sure, the [Choice Scholarship Pilot Program] does not explicitly funnel money directly to religious schools, instead providing financial aid to students.").

189. N.M. Ass'n of Non-public Schs. v. Moses, 137 S. Ct. 2325 (2017) (mem.); Moses v. Skandera 367 P.3d 838 (N.M. 2015).

190. Moses, 367 P.3d at 839-40.

191. Id. at 840 .

192. Id.

193. Id. at 841 .

194. Id. 
state's program violated the state Constitution. ${ }^{195}$ "The broad language of this provision and the history of its adoption and the efforts to amend it evince a clear intent to restrict both direct and indirect support to sectarian, denominational, or private schools, colleges, or universities." 196 Similar to the Colorado case, the New Mexico Supreme Court found that its Constitution is more restrictive than the United States Constitution regarding the public funding of religious purposes.

In reexamining the issue after the Supreme Court's remand, the New Mexico Supreme Court will likely find the program constitutional. Because the New Mexico program aimed to improve all schools, whether private or public, any exclusion of religious schools by virtue of their religious status would violate of the Free Exercise Clause. Limiting the public program to only secular schools falls into the same trap Missouri fell into. ${ }^{197}$ A state must have a compelling interest to withhold a generally available public benefit from religious institutions. ${ }^{198}$ Unless New Mexico can provide a compelling reason for preventing the state from helping religious schools buy educational material, then New Mexico would likely be violating the Free Exercise Clause.

Both the Colorado case and the New Mexico case demonstrate the impact of the Trinity Lutheran decision. Now, governmental programs offering a public good, but restricting the public good from religious institutions, will face Free Exercise scrutiny. While it is still possible to uphold this discrimination, such provisions must now pass strict scrutiny.

These two cases demonstrate the potential difficulty in applying the Trinity Lutheran holding. There's no perfect test from Trinity Lutheran to apply to these subsequent cases. If courts use the totality of prior precedent - such as a test combining the indirect/direct distinction with a public program distinction-lower courts can apply the Trinity Lutheran distinction more easily. As further explained below, these distinctions are key to developing a clear test for similar religious liberty cases.

While Trinity Lutheran helped empower the Free Exercise argument against the Blaine Amendments, some have questioned whether these nofunding provisions violate the right to Free Speech. ${ }^{199}$ While these Free (finding that "Missouri's policy preference for skating as far as possible from religious establishment concerns" cannot qualify as a compelling interest "[i]n the face of the clear infringement on free exercise" at issue).
}

199. For a detailed analysis on Blaine Amendments and Free Speech, see DeForrest, supra note 
Speech arguments have not always been persuasive to the courts, they are still worthy of consideration. For example, Trinity Lutheran appealed the district court's ruling, except on their Free Speech claim. ${ }^{200}$ Some argue that the lack of support for religious organizations alongside support for secular organizations amounts to viewpoint discrimination. ${ }^{201}$ The Supreme Court has held that the denial of generally available funds from private parties on the basis of their religion constitutes viewpoint discrimination and violates the First Amendment. ${ }^{202}$ While there is some precedent applying this view to no-funding provisions, courts tend to find that the states' attempts to avoid Establishment Clause issues is enough of a compelling reason for the Free Speech violations. ${ }^{203}$ As such, Free Exercise complaints are generally more effective in combatting the various no-funding provisions. Free Speech was not raised on appeal in Trinity Lutheran and the resulting success in that case for religious freedom advocates supports attacking no-funding provisions from a Free Exercise perspective instead of a Free Speech perspective.

\section{B. Implications for the Doctrine of Separation of Church and State}

No-funding provisions have seemingly become the doctrine of separation of church and state. As discussed in Section I.A.2 regarding the motivations behind the Blaine Amendments, this was not the original formulation. Looking at the key figures behind the support for these nofunding provisions shows that the purpose was to retain a support of "generic Protestantism" in the public sphere. ${ }^{204}$ As this purpose slipped away, the no-funding provisions' association with the separation of church and state emerged. This has clouded the proper relationship the state should have with religion. Further, the current understanding of the separation of church and state may lead to unfair discrimination against religious organizations such as in Trinity Lutheran. Trinity Lutheran seemingly helps address this issue, however, learning to navigate religious

203. DeForrest, supra note 4, at 622 ("[I]t is critical to note that the Supreme Court has recognized that Establishment Clause violations constitute a compelling state justification for content-based restrictions against religious speech.”).

204. Id. at 602 ("[T]here was an almost imperative desire on the part of the proponents of the Blaine Amendment to protect generic Protestant religiosity in the common schools and the public square.").
} 
freedom cases post-Trinity Lutheran will be the next hurdle for courts. Prior Supreme Court cases may provide an answer to this problem.

Currently, Supreme Court cases rely on several key distinctions in religious freedom situations. First is the indirect/direct aid distinction. Direct federal aid of religion is almost always found to be unconstitutional. $^{205}$ Indirect aid is given more leeway. ${ }^{206}$ Yet even then, courts can find indirect aid unconstitutional, such as in Locke. ${ }^{207}$ The reason for this leads to the second key distinction the Supreme Court uses in religious freedom cases, the religious use/religious status distinction.

The Trinity Lutheran majority used the religious use/religious status distinction to find Missouri's actions violated the Free Exercise Clause. ${ }^{208}$ Justice Gorsuch may end up vindicated in his criticism of this distinction that this distinction is not helpful. The overlap between the two concepts is too broad for effective use in religious freedom cases. While a test based on religious use/religious status is a simpler test to apply, it is an overbroad distinction that courts will struggle to apply to case-specific facts.

Trinity Lutheran appears to add another distinction: whether the funding is part of a publicly available program. ${ }^{209}$ If a state ties funding to one of these programs, the funding of religious institutions (whether direct or indirect funding) appears to be more constitutional.

Expanding the direct/indirect aid distinction to include the public program distinction from Trinity Lutheran would create a better test. This test would harmonize the Court's decisions in Zelman and Trinity Lutheran while leaving the no-funding provisions with some teeth. This test can combine Zelman's holding that indirect funding is constitutional due to private choice and Trinity Lutheran's holding that a state cannot prevent religious groups from participating in publicly available programs. This test would allow direct funding of religious institutions if that funding comes from a program open to the public i.e. Trinity Lutheran. Further, courts would likely allow indirect funding as long as it was through the

205. See Lemon v. Kurtzman, 403 U.S. 602, 625 (1971) (finding a Pennsylvanian statute that provided state financial aid directly to private religious elementary and secondary schools unconstitutional).

206. See Zelman v. Simmons-Harris, 536 U.S. 639, 649 ("[O]ur decisions have drawn a consistent distinction between government programs that provide aid directly to religious schools and programs of true private choice, in which government aid reaches religious schools only as a result of the genuine and independent choices of private individuals." (citations omitted)).

207. Locke v. Davey, 540 U.S. 712,728 (2004).

208. Trinity Lutheran Church of Columbia, Inc. v. Comer, 137 S. Ct. 2012, 2024 (2017) ("The State has pursued its preferred policy to the point of expressly denying a qualified religious entity a public benefit solely because of its religious character. Under our precedents, that goes too far. The Department's policy violates the Free Exercise Clause.").

209. Id. 
action of private individuals. Finally, this test would leave the courts the ability to use the Blaine Amendments to block religious funding that falls outside of these two distinctions.

However, this test would conflict with some prior precedent. For instance, the current understanding of Locke would be bad law, but Justice Gorsuch's Trinity Lutheran concurrence provides a way to remove the religious use/status distinction while retaining Locke. ${ }^{210}$ There are many ways to distinguish Locke that preserve the direct/indirect funding distinction. For instance, while a court could deem the Washington Constitution's ban on indirect funding of religious institution unconstitutional, the court could still prevent funding of religious clergy, thereby distinguishing Locke.

Whatever way the courts decide to go, a test merging Zelman and Trinity Lutheran is the proper test to adopt, expand, and use in religious freedom cases. This test is easier for the lower courts to apply and would likely lead to less religious freedoms cases brought before the Supreme Court. Further, a test based upon these distinctions attacks the heart of the issue regarding no-funding provisions-whether public money can go towards religious institutions and to what degree this is constitutional. The religious status/religious use distinction is difficult to apply because religious status can look a lot like religious use and vice versa. Looking to only two elements, direct/indirect funding and public programs, grants clarity to an often cloudy and confusing realm of law. Its adoption would help clear up this area of law by giving the courts a practical test to apply.

However, as with all good tests, there must be some nuance in its application. Courts should still factor in other elements like the degree of private choice and the neutrality of the program. A factor test would improve the test's flexibility, allowing it to be applicable and used in a variety of situations.

\section{Implications for the "School Choice" Movement}

The questionable constitutionality of the Blaine Amendments has long been a center-piece of the school choice movement. However, this movement's victory may not be as sweet as once hoped. Public funding of religious schools has some concerning aspects that may worry religious leaders. For one, governments tend to tie public money to governmental oversight. ${ }^{211}$ Allowing public money to flow directly into religious

210. Id. at 2026 (Gorsuch, J., concurring).

211. Marjorie Reiley Maguire, Comment, Having One's Cake and Eating It Too: Government 
schools would require government standards to apply in the classrooms. ${ }^{212}$ Federal or state educational standards could bring mandates to teach topics such as evolution, which most fundamentalist Christians reject. ${ }^{213}$ In all likelihood, this would lead to some of the more "fervent" religious schools opting out of receiving any public funding.

The elephant in the room is school vouchers. ${ }^{214}$ School vouchers provide a way for public money to flow into religious schools without governmental standards becoming protrusive. ${ }^{215}$ In essence, the state attaches funds to a child and those funds flow to whatever school they chose, religious or public. This is why school vouchers are at the focal point of this fight. The Trinity Lutheran decision seemingly adds fuel to the fire regarding this topic. Supporters of school vouchers now have an argument in that if secular private schools receive school vouchers, restricting private schools from these programs would seemingly violate Trinity Lutheran. Foreseeing this issue, the Court tried to limit its holding to the facts of the case. ${ }^{216}$ Furthermore, the Court sent back a Colorado case involving school vouchers in order to have the Colorado court apply Trinity Lutheran to a school vouchers case. ${ }^{217}$ As previously mentioned,

Funding and Religious Exemptions for Religiously Affiliated Colleges and Universities, 1989 WIS. L. REV. 1061, 1066 n.22 (1989) ("Rather, some American Catholic institutions, as well as some other religiously affiliated institutions, are caught between their desire for public money and their desire to be free of public oversight of their decisions."); See Ibby Caputo and Jon Marcus, The Controversial Reason Some Religious Colleges Forgo Federal Funding, ATLANTIC (Jul. 07, 2016), https://www.theatlantic.com/education/archive/2016/07/the-controversial-reason-some-religiouscolleges-forgo-federal-funding/490253/.

212. Andrew Coulson, Do Vouchers and Tax Credits Increase Private School Regulation? 14 (CATO Inst. Working Paper, Paper No. 1, 2010), https://object.cato.org/sites/cato.org/files/pubs/pdf/ WorkingPaper-1-Coulson.pdf (arguing that school vouchers would lead to an increase in governmental regulations while tax credits for education would not).

213. Stephanie L. Shemin, The Potential Constitutionality of Intelligent Design?, 13 Geo. MASON L. REV. 621, 626-627 (2005). "Although Christian fundamentalists are the group most often associated with anti-evolutionist activism ... they are not the only group that questions evolution or prefers to believe that the origin of life was the work of a deity. For example, Catholics, mainline Protestant denominations, and Orthodox Jews subscribe to some form of belief in theistic evolution." Id. at 664 n.294.

214. Becoming popular largely due to the "school choice" movement, "voucher" became the nomenclature due to Friedman's support of the concept in Capitalism and Freedom. Friedman largely tied the purpose behind this concept to the maximization of freedom which has seen the concept of school vouchers become increasingly supported by those influenced by Libertarianism. Stephen D. Sugarman, Is it Unconstitutional to Prohibit Faith-Based Schools from Becoming Charter Schools?, 32 J.L. \& RELIGION 227, 230-31 (2017).

215. Coulson, supra note 212, at 14 .

216. See Trinity Lutheran Church of Columbia, Inc. v. Comer, 137 S. Ct. 2012, 2024 n.3 ("This case involves express discrimination based on religious identity with respect to playground resurfacing. We do not address religious uses of funding or other forms of discrimination.").

217. Colo. State Bd. of Educ. v. Taxpayers for Pub. Educ., 137 S. Ct. 2325 (2017). 
the Colorado case will quickly demonstrate how some courts will apply Trinity Lutheran to school vouchers.

Education savings accounts (ESAs) present a similar problem as vouchers. ${ }^{218}$ ESAs are already in use in five states but are mostly limited to students with special needs. ${ }^{219}$ Recently, Nevada created an expansive ESA program that went beyond the bounds of other states. ${ }^{220}$ The policy was challenged and went before the Nevada Supreme Court where the court upheld the ESAs but found the funding mechanism unconstitutional. ${ }^{221}$ While both school vouchers and ESAs offer more "mainstream" ways to give public support to religious schools, religious charter schools offer another alternative. ${ }^{22}$ ESAs offer the same "indirect" support that school vouchers would achieve. Further, this indirect funding gives parents more freedom to choose how to fund their children's education. They can use the money for a private elementary or high school or save the money to pay for a college education.

Whether the states move toward school vouchers or ESAs, courts will run into hurdles when reviewing these school funding methods for constitutionality. As official government programs, they will have to pass the Lemon test. Yet, now the courts will also have to balance that with the precedent established in Trinity Lutheran. Courts must judge the constitutionality of a government program entangling government and religion, while considering that denying religious institutions access to the program violates the Free Exercise Clause. This conflict will inevitably bring a challenge before the Supreme Court, offering the Court an opportunity to clarify the topic of public funding for religious institutions. The Court should take that opportunity to endorse the use of a test which the lower courts can use to address religious freedom issues and conflicts with state no-funding provisions. Formulating a test centered on the indirect/direct funding distinction offers a flexible test for courts to solve complex religious freedom cases and to create a clearer line between church and state.

\footnotetext{
218. Jason Bedrick, Nevada Supreme Court: Education Savings Accounts Are Constitutional, Funding Mechanism Isn't, CATO AT LIBERTY BLOG (Sept. 29, 2016, 3:43 PM), https://www.cato.org/blog/nevada-supreme-court-education-savings-accounts-are-constitutionalfunding-mechanism-isnt.

219. Id.

220. Id.

221. Id.; Schwartz v. Lopez, 382 P.3d 886, 891 (Nev. 2016).

222. See Sugarman, supra note 214 , at 260-62.
} 


\section{CONCLUSION}

Though the majority of Americans support the separation of church and state, they are unaware of the discriminatory basis of its current application. The Blaine Amendments are still tainted by the prejudice of their initial supporters, and while Kansas's version may or may not share the same prejudicial view as its proposed federal counterpart, it, and other state no-funding provisions, has helped stifle the debate about the proper role of public funding for religious schooling. Trinity Lutheran may serve as a landmark case in the field of religious freedom as it limited the applicability of these no-funding provisions. With the Supreme Court's established precedent, there may finally be enough case law to overturn the various no-funding provisions, including Kansas's. Further, prior precedent gives the tools to craft a test to address these types of cases in the future. Kansas does not have any applicable reason to continue abiding by its own no-funding provision in indirect aid situations. It may be years until Kansas reaches this conclusion, yet the pieces are in place for Article 6 , Section 6 of the Kansas Constitution to be declared unconstitutional when applied to situations involving indirect educational aid to religious organizations. 